WALTER SCOTT: THE MAKING OF THE NOVELIST 
This page intentionally left blank 


\section{JANE MILLGATE}

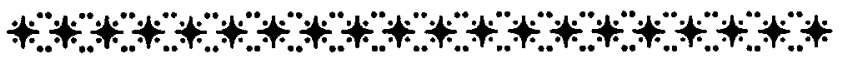

\section{Walter Scott: \\ The Making of the Novelist}

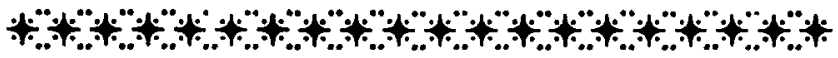

UNIVERSITY OF TORONTO PRESS

Toronto Buffalo London 


\title{
www.utppublishing.com
}

- University of Toronto Press $198_{4}$

Toronto Buffalo London

Printed in Canada

ISBN 0-8020-2527-7

\section{Canadian Cataloguing in Publication Data}

\author{
Millgate, Jane. \\ Walter Scott : the making of the novelist \\ Includes bibliographical references and index. \\ ISBN 0-8020-2527-7 \\ I. Scott, Walter, Sir, 177 I-1 832 - Criticism and \\ interpretation. I. Title. \\ $\mathrm{PR}_{5341 . \mathrm{M}_{54} 198_{4} \quad 83^{\prime} \cdot 7 \quad \mathrm{C}_{3}-099231-6}$
}

Part of chapter seven of this book appeared in an earlier version in Nineteenth-Century Fiction 34, no 4 (1980) 379-96 (C) I980 by the Regents of the University of California) and is reprinted by permission of the Regents.

Publication of this book is made possible by grants from the Canadian Federation for the Humanities, using funds provided by the Social Sciences and Humanities Research Council of Canada, and from the Publications Fund of University of Toronto Press. 